\title{
Ssciendo
}

\section{Towards a Managerial Public Service Bargain: The Estonian Civil Service Reform}

\author{
Cerlin Pesti ${ }^{1}$, Tiina Randma-Liiv ${ }^{2}$
}

\begin{abstract}
The aim of this article is to explore and explain the 2012 civil service reform in Estonia. The study builds on the concept of public service bargain, which facilitates the operationalization of changes in the civil service system. Although public service bargain has attracted a lot of interest of public administration scholars, it has not been previously applied in the civil service research in Central and Eastern Europe. The theoretical part synthesizes previous literature on typologies of public service bargain, thus elaborating an analytical framework for the empirical study. The empirical study addresses the following research question: did the civil service reform change the public service bargain in Estonia and if so, how? The empirical research was carried out by relying on desk research, secondary literature on Estonian administrative reforms and participant observation. The study builds partly on the materials collected for the EUPACK case study on Estonia. The analysis shows that the civil service reform brought along changes in all three components of public service bargain: reward, competency and loyalty, although the agency-type bargain was retained. The shift towards the managerial public service bargain is evidenced in the greater emphasis on flexibility in employment relations, the use of fixed-term contracts, increased private-sector-style practices at all levels of the civil service, an emphasis on performance management, and the reduction of job security. Despite the widespread criticism of NPM, the Estonian civil service reform presents a "textbook case" of managerial NPM-oriented reform. It is argued that substantially diminished rewards may contribute to a vicious circle of temporary civil servants, including problems with recruiting new officials and a further increase in their turnover, ultimately leading to a "temporary state". The loyalty of civil servants may in turn shift towards instrumental, short-term and easily influenced or changing loyalty, thus challenging the fundamental values of democratic governance.
\end{abstract}

1 PhD student in Public Administration, Tallinn University of Technology, Tallinn, Estonia.

2 Professor of Public Policy, Tallinn University of Technology, Tallinn, Estonia. 


\section{Introduction}

Some authors have used rather modest terms when referring to the administrative reforms of the last decade, not only in Estonia but in all of Central and Eastern Europe, such as "unfinished or non-implemented reforms" (Nemec 2010), "fine-tuning" (Randma-Liiv and Drechsler 2017) and "piecemeal initiatives" (Savi and Randma-Liiv 2016). As exogenous factors related to post-communist transformation and the EU accession behind public administration reforms disappeared, endogenous (domestic) factors obtained a greater role than ever before. Public administration reform has been hardly perceived as a political priority, which is why the pace and depth of administrative reforms slowed down once outside pressure to take hard decisions declined. This is why, in sharp contrast to periods of post-communist transformation and the following EU accession, the last decade has not witnessed all-encompassing central government reforms in Estonia. There is one major exception to this general observation - the civil service reform in 2012.

Civil service constitutes a key element in any administrative system, especially so in new democracies, as civil service reform was considered the most crucial component of the "administrative capacity" requirement of the EU's Eastern enlargement (Dimitrova 2002) and because several post-communist countries have recently experienced reform reversal towards politicization and centralization, which clearly threaten the fundamental features of democratic governance (Randma-Liiv and Drechsler 2017). The aim of this article is to explore and explain the 2012 civil service reform in Estonia.

Civil service systems are inherently "path dependent", owing to their robust institutional arrangements that are, at times, entrenched in specific legal orders (Bezes and Lodge 2015). Reforms are "embedded" in the legacies of civil service systems: the key features of civil service systems cannot be reversed easily (Bezes and Lodge 2015). This study builds on the concept of public service bargain (hereinafter PSB; Hood and Lodge 2006), which will serve as the basis for the theoretical framework by facilitating the operationalization of changes in the civil service system. Public service bargain has been defined as "any explicit or implicit understanding between public servants and other actors in a political system over their duties and entitlements relating to responsibility, autonomy and political identity, and expressed in convention or formal law or a mixture of both" (Hood and Lodge 2006, 6). According to the PSB, politico-administrative relations are based on an implicit or explicit bargain between the two parties whereby, to put it simply, the political masters expect competence and loyalty from the civil servants and the latter expect some mixture of rewards (both tangible and intangible) and autonomy in a particular responsibility area in return (Burns et al. 2013; Hood and Lodge 2006). PSBs can be formally enacted in constitutions, laws, civil service statutes and ethical codes (systemic PSBs) or informal understandings between the actors involved in the bargains reflected in normative role expectations (pragmatic PSBs) (Salomon- 
sen and Knudsen 2011). Although the concept of PSB has attracted a lot of interest by public administration scholars (see, e.g., Bezes and Lodge 2015; Hondeghem and Van Dorpe 2012; Hood 2000, 2001, 2002; Lodge and Hood 2012), leading to a collection of single-country case studies (e.g. Althaus and Vakil 2013; Burns et al. 2013; Salomonsen and Knudsen 2011; Steen and Van der Meer 2011), it has not been previously applied in the civil service research in Central and Eastern Europe.

The study addresses the following research question: did the civil service reform change the public service bargain in Estonia and if so, how? The Estonian civil service system offers an interesting example because it is one of the most decentralized systems in Europe (Meyer and Hammerschmid 2010) with much discretion delegated to single organizations, as each ministry and executive agency is responsible for the recruitment, training, performance appraisal and pay of its officials. It is an extremely open system where it is possible to enter the civil service without any restrictions on any level. The 2012 reform turned the civil service system even further towards decentralization and managerial discretion. As reform trends in several countries refer to the decentralization of civil services (Lægreid and Wise 2015), the Estonian case demonstrates what impact such decentralization-oriented reforms may have on public service bargain.

The empirical research was carried out by means of desk research, mostly on the basis of Internet sources (e.g. legislative acts and their explanatory letters) and of secondary literature on Estonian administrative reforms. The study builds partly on the materials collected for the EUPACK case study on Estonia (Pesti and RandmaLiiv 2017). This has been complemented by participant observation, as one of the authors served as head of the Public Administration and Public Service Department at the Estonian Ministry of Finance during the adoption of the new Public Service Act in 2012 and its enforcement in 2013. The civil service reform has not been previously covered in academic literature despite its high importance in Estonian public administration.

\section{Theoretical framework: public service bargain}

\subsection{Types and sub-types of public service bargain}

The meaning and substance of public service bargain may vary across time and space, and even across particular jobs. As PSBs vary according to the institutional context in which bargains are made, and their degree of formality may differ, there are distinctive forms of bargains. This has laid a basis for the development of typologies of PSB presented in Table 1 (Hood and Lodge 2006). 


\section{Table 1}

Types and sub-types of public service bargain (based on Hood 2000 and Hood and Lodge 2006)

\begin{tabular}{|l|l|}
\hline \multicolumn{1}{|c|}{ Broad type } & \multicolumn{1}{c|}{ Sub-type } \\
\hline \multirow{2}{*}{ Systemic or trustee (autonomy) bargain } & Consociational bargain \\
\hline \multirow{4}{*}{ Pragmatic or agency bargain } & Hegelian or Confucian bargain \\
\cline { 2 - 2 } & Schafferian bargain (serial loyalist) \\
\cline { 2 - 2 } & Hybrid bargain (personal loyalist) \\
\cline { 2 - 2 } & Managerial bargain \\
\hline
\end{tabular}

The early typology by Hood (2000) distinguishes between two major forms of bargains: a systemic and a pragmatic bargain. In the systemic bargain, the role of the public service is part of a fundamental constitutional settlement, while in the pragmatic bargain, rights and duties of public servants are a more or less convenient agency arrangement between politicians and civil servants. The later typology by Hood and Lodge (2006) distinguishes between two major types of bargain: a trustee and an agency bargain. The trustee bargain corresponds to the systemic bargain and the agency bargain to the pragmatic bargain (Hood 2002). In the trustee bargain, public servants are expected to possess a certain autonomy and defend the public good. In such bargain the tenure, rewards and competency of public servants are not under direct political control, and public servants are loyal to an entity broader than the government in office (Hood and Lodge 2006, 24-25). In the agency bargain, public servants are the agents of the political principal and act upon the political principal's will. Public servants (agents) are expected to follow lawful orders of politicians (principals), and politicians in turn are responsible for the actions of public servants. Politicians directly control the rewards and tenure of public servants; the skills and competency required from public servants are those needed to do the politicians' bidding; and public servants are loyal to politicians only. The agency bargain is seen as necessary for bureaucratic responsiveness in democratic government (Hood and Lodge 2006, 43-47).

Sub-types of the systemic bargain are the consociational and the Hegelian bargain, and sub-types of the pragmatic bargain include the Schafferian, the hybrid and the managerial bargain (Hood 2001). In consociational bargain, where the public service is expected to be representative of the society and the public service receives a share in the administrative power of the state in exchange for a consolidation of existing power relations, the PSB is more difficult to change (Hood and Lodge 2006). In a consociational PSB, members of different social-demographic groups in the public service provide "glue" to bond the society together. According to the second type of systemic PSB, the Hegelian bargain, public servants are not seen as mere agents of politicians, but as quasi-autonomous actors functioning as guardians 
or trustees of the welfare of the society or the constitutional order as a whole (Hood and Lodge 2006).

The best documented bargain is the first sub-type of pragmatic bargaining - a Schafferian bargain, which used to be dominant in Westminster-type civil service systems (Hood 2001). In this model, public servants provide loyalty and competent service to the government of the day in exchange for trust, anonymity, merit selection and permanent tenure. The traditional Schafferian concept defines career public servants as confidential government advisers "speaking truth to power" with permanent tenure, trust by ministers and with avoidance of public blame for policy (Hood 2001, 16-17).

As a result of New Public Management (NPM) reforms, a new bargain emerged, called the managerial PSB - especially relevant for top civil servants (Hood 2000). This bargain implies more autonomy for top officials in exchange for increased responsibility, including the blame for mistakes. It means that top civil servants typically receive more autonomy in organizing public services, accepting in exchange the blame in cases of unsatisfactory results or mistakes. In line with the private sector practice, conditions and working relationships for civil servants are person-specific and individually negotiable. Attempts at bureau-shaping or resistance to more rigorous control frameworks have been found to be common in the politics of public service managerialism (Hood 2000, 19).

Situated between the Schafferian and managerial PSBs is hybrid PSB, where politicians share blame with public servants rather than transferring it to them, and public servants have no defined sphere of autonomy. According to Hood (2001), pure managerial PSBs did not generally replace Schafferian ones, but the move seems to have been to hybrid bargains or mixed Schafferian-managerial ones. This means that older parts of the PSB may still persist, resulting in hybrid bargains with limited characteristics of managerial bargain. Hondeghem and Van Dorpe (2012), in turn, suggest that the "managerial" category should be further refined, making a distinction between "strong", "moderate" and "weak" managerial bargains. In doing so, fewer cases would end up in the "hybrid" category as a residual category, and this category could thus retain its value (Hondeghem and Van Dorpe 2012, 23).

These types and sub-types present a large variety of possible PSBs. There are no clear-cut lines between the different sub-types but in most cases it is possible to identify a dominating type and sub-type of PSB. The types and sub-types of PSB are not static but can shift as a result of civil service reforms. One could even argue that the depth of the civil service reform is reflected by the change in PSB typology.

\subsection{Components of public service bargain}

Public service bargains vary along three components: rewards, competency and loyalty (Hood and Lodge 2006). The definition of components may differ, as well as their relative weight in PSB (Hood and Lodge 2006). For each component, Hood 
and Lodge (2006) have developed a distinct typology, based on grid-group theory (see Table 2).

Table 2

Components of public service bargain (Hood and Lodge 2006)

\begin{tabular}{|l|l|}
\hline \multicolumn{1}{|c|}{ Components } & \multicolumn{1}{c|}{ Types } \\
\hline \multirow{4}{*}{ Reward } & Pyramid or elevator \\
\cline { 2 - 2 } & Noblesse oblige \\
\cline { 2 - 2 } & Turkey race \\
\cline { 2 - 2 } & Lottery of life \\
\hline \multirow{4}{*}{ Competences } & Wonks \\
\cline { 2 - 2 } & Go-betweens and brokers \\
\cline { 2 - 2 } & Deliverers \\
\cline { 2 - 2 } & Sages \\
\hline \multirow{5}{*}{ Loyalty/responsibility } & Judge \\
\cline { 2 - 2 } & Partner \\
\cline { 2 - 2 } & Executive \\
\cline { 2 - 2 } & Jester \\
\hline
\end{tabular}

The first component of PSB - reward - resembles inducements and explicates what the civil servants receive in return for their contribution (Hood and Lodge 2006, 21). The politics of rewarding civil servants and their career management has been at the heart of considerable debate. The rewards-related dimension reflects on tangible and intangible rewards, including salaries and pensions, expectations regarding career advancement, and the degree of permanency of the position or the risk of dismissal. Hood and Lodge $(2006,69)$ identify four types of reward bargain: the "pyramid" or "elevator" type, "noblesse oblige", "turkey race", and "lottery of life". The "pyramid" or "elevator" type of reward includes a structured hierarchy of rewards with expectations of orderly and predictable progression. "Noblesse oblige" or "rent non-seeking" bargain contains relative self-restraint of pay at the top ranks of civil service in exchange for the honor and social respect coming with a high status as well as inner satisfaction. "Turkey race" bargain means that there is an agreement where rewards based on individual competition and variable rewards play an important role. "Lottery of life" bargain involves non-automatic or unpredictable rewards, sometimes depending on luck and chance, and rewards being relatively independent of individual skills, desert, or sagacity. The "managerial age" of the late $20^{\text {th }}$ century is said to have challenged many of the traditional reward patterns (Bezes and Lodge 2015). As a consequence of NPM reforms (Bezes and Lodge 2015), accompanied by an aging population and fiscal consolidation (Lodge and Hood 2012, 96), there has been 
general downward pressure on monetary rewards, a decrease of pensions, and a raise of the retirement age. As a result, in managerial PSB, reward is characterized by less permanency, lateral entrance, competition for promotion, competitive and performance-related pay. It can be described as a "turkey race" type of PSB. PostNPM is expected to lead to a reduction in the extent to which performance pay is provided and in the way it is being distributed, in particular moving away from individualized to more team-based incentive systems (Lodge and Gill 2011, 151).

The second component of PSB is competency, which refers to key aspects regarding professionalization in terms of required qualifications and skills, appointment processes and training. Although competence can be seen as one of the most important criteria in modern meritocratic civil service systems (Peters 2010, 83), the substance and relative weight of different competency requirements may vary across states, organizations, jobs or preferences of single managers (Hood and Lodge 2006, 91-92). Hood and Lodge (2006) describe four types of competency bargains: "wonks", "go-betweens and brokers", "deliverers", and "sages". In "wonks" bargain, public servants can rule over particular fields where they own technical skills. Similar to "wonks" bargain is "go-betweens and brokers" bargain, which puts the emphasis on public servants' ability to straddle and bring together different "worlds", acting as facilitators, brokers, diplomats, or go-betweens rather than operating within a chain of command. This refers to civil servants' abilities related to political craftsmanship (see also Askim and Bach 2017). In contrast to "wonkish" and "spanning" competencies, at the heart of "delivery"-type competency bargains lies the individual's ability or "... the skill of being able to make things happen within a government organization in a desired way, rather than just following rules or routines ..." (Hood and Lodge 2006, 98). The competency of the "sage" is to provide intellectual or moral insight rather than to rule or to make deals among groups. It assumes that officials' knowledge comes from innate qualities and experience and cannot readily be taught at universities (e.g. the ability to identify and assess political risks intuitively). A managerial PSB resembles more a "deliverer" type of PSB because managerial skills are regarded as more important than technical skills, and in line with the managerial approach, result-orientedness is highly valued. According to Lodge and Gill (2011), the key differences of the age of NPM and the age of post-NPM lie in the competency dimension: whereas an NPM-type PSB emphasizes the importance of "delivery" within one organization (justified by the idea of "focus" and "specialization"), the underlying competency ideas represented in the post-NPM literature stress the importance of boundary spanning and collaboration (Lodge and Gill 2011, 151).

The third component of PSB relates to responsibility and loyalty - the level of autonomy of decision-making of public servants relative to politicians. It can turn out to be more crucial than competencies for the parties of PSB (Hood and Lodge 2006, 110; Rouban 2012, 386). On the one hand, public servants are expected to be loyal to the state, public interest and government as an institution; on the other 
hand, politicians often expect public servants to be committed to their political goal (serial loyalist) or a particular minister (personal loyalist) (Hood and Lodge 2006). These two potentially contradicting expectations may lead to a variety of loyalty conflicts in the relationships between politicians and public servants, and ultimately to a politicization of the civil service (Rouban 2012). There are four types of loyalty bargains: "judge" type, "partnership", "executive", and "jester" type (Hood and Lodge 2006). In the "judge" type of bargain, public servants demonstrate loyalty to the state and the law, and they act as semi-autonomous players with loyalty to some higher entity partly or wholly interpreted by themselves - the department, the law, the constitution, public interest, citizens, etc. At the opposite pole of the "judicial" type bargain comes the "partnership" bargain, in which public servants work together with elected politicians but have no separate identity, either in directing public organizations or in determining policy. Such arrangements mainly apply to what has been termed "loyalist", whether "personal" (hybrid-type bargain) or "serial" (Schafferian-type bargain) (Hood and Lodge 2006). By an "executive"-type loyalty bargain, bureaucrats are separately identifiable as individuals but are not free agents in any political sense - they are pursuing defined goals in some limited and revocable space of action. In a "jester"-type loyalty bargain, certain individuals are given licence within some usually undefined limits to operate as jokers or as reality checkers for rulers. A managerial PSB is an "executive" type of PSB because loyalty is foremost expected towards the principal who is in charge, performance may be defined in an individual performance agreement which is subjected to severe close control. Political affiliation is not an issue, as management is regarded as a neutral matter. In case of failure, blame rests with the manager.

In sum, civil service systems can be understood as systems or interdependent complementary dimensions. Any reform on one dimension will have direct implications on other aspects of the bargain. For example, attempts at fiddling with rewards will have implications not just in terms of motivation, but also on loyalty and competency (Bezes and Lodge 2015, 141). The empirical study of the Estonian civil service reform below demonstrates that PSB and its components provide a good foundation for the operationalization and systematization of the analysis of civil service reform.

\section{The Empirical Study: Civil Service Reform in Estonia}

\subsection{Development of the Estonian civil service}

The first Public Service Act (PSA1) of post-Communist Estonia came into force on 1 January 1996 and was in effect until 2013. It determined the scope of public service in Estonia according to which the public service covers only a small part of the public sector workforce - people working for the ministries, government agencies, local government institutions and a few other state institutions, i.e. at the core 
of the public sector. This study focuses solely on the civil service (central government). PSA1 created the basis of a modern merit civil service system by abolishing the patronage system through the introduction of recruitment and promotion on merit, regular appraisal, and unified grading and salary scales throughout the civil service. The civil service was based on the principles of a job system, with a few elements drawn from a career system. A few branches within the civil service were (and still are) career-based and were (are) regulated by special statutes: foreign service, police service, border guard, the court system and a few institutions within the administrative area of the Ministry of Defense. PSA1 left recruitment open for all posts in the civil service, the senior civil service included. Open competitions for senior positions were publicly announced. Civil servants were recruited on a permanent basis as a rule; fixed-term contracts were used for temporary staff and for a limited number of senior civil servants. However, despite permanent employment, it was relatively easy to dismiss civil servants, although it put some financial pressure on individual government institutions. Human resource management in the civil service was, and still is, almost entirely decentralized in Estonia (Järvalt and Randma-Liiv 2010), making it one of the most decentralized civil service systems in Europe (Meyer and Hammerschmid 2010). Since 1996, every ministry and executive agency has been responsible for the recruitment, probationary periods, training, performance appraisal, promotion and work organization of their officials. The civil service commanded relatively low prestige, and the level of remuneration of professionals was not competitive with salaries in the private sector.

Until 2012, there had not been major civil service reforms since the adoption of PSA1 in 1995. All consecutive governments at the end of the 1990s and the beginning of the 2000s had some kind of public administration reforms - including civil service reforms - on their agendas. However, in most cases, these addressed individual elements of the civil service (e.g. pay reform) and were often of a technical nature. Several one-off initiatives never materialized. Since the adoption of PSA1, the Cabinet of Ministers accepted the draft of a new Public Service Act twice (in 2002 and 2009) and sent it to the parliament. Drafts passed first reading both times but did not reach the second reading due to political disagreements, and no decision was reached before new general elections (respectively in 2003 and 2011).

The lack of overall progress in civil service reform appeared to be due largely to the absence of a broad underlying consensus on the direction of reform. There was neither very strong opposition nor a strong political interest in maintaining the status quo. In general, civil service development has never been high on the Estonian political agenda. Individual government organizations (e.g. Ministries of Justice and of Finance) came up with some reform ideas from time to time, but these did not reach the political level and did not materialize in legal changes. Because of the long postponement of the civil service reform, Estonia was a case in which the legal basis and the actual practices of civil service policy were occasionally seen as 
two different worlds (Meyer-Sahling 2011). As a result, the necessity to decrease the gap between legal text and actual practice became indispensable.

The prevailing neo-liberal ideology in Estonia has legitimized using private sector concepts and considering the state to be a "corporation" in the development of civil service and in public sector human resource management. Public sector reforms have predominantly aimed at reducing costs (Savi and Randma-Liiv 2016). The cost-efficiency motive behind public sector reforms remained acute even during the years of the economic boom in the early 2000s. It was further accelerated during the fiscal crisis in 2008-2012, which hit Estonia particularly hard. Although the fiscal crisis did not cause major administrative reforms in Estonia, it gave a boost to several initiatives that had been discussed before and that aimed at costsaving. One of those initiatives was the civil service reform.

The right-leaning coalition which came into office in 2011 took the previous law draft (2009) as a basis, and a very similar Public Service Act (PSA2) was adopted by the parliament in 2012, which came into force in April 2013. The reform further endorsed the open and segmented nature of the Estonian public administration and aimed to decrease the number of civil servants and to abolish the perceived "disparities" that there were between the civil service and private sector employment. Specific changes in the civil service system will be elaborated below in the context of the components of PSB.

\subsection{Rewards}

According to the public service bargain, rewards include both monetary and nonmonetary rewards, such as employment conditions, job security, career advancement, pay and pension.

PSA2 restricted the former institutionally based narrow definition of the civil service even more and re-oriented the system towards differentiating officials who are engaged in executing public power and employees who do not have this responsibility. The goal was to reduce the number of civil servants. As a result of the reform, about $25 \%$ of civil servants lost their status and became employees under the Labor Law. Not only was the definition of "civil service" restricted, but the civil service employment conditions presented in PSA2 became by and large equal to that provided by the Labor Law. This way PSA2 abolished the perceived "disparities" that there were between the civil service and private sector employment. This established the public service as "any other employer" in the labor market. For example, although civil servants were and are recruited on a permanent basis as a rule, public service job security, which had already been limited, was reduced even more by PSA2, and conditions for terminating a job became exactly the same as in the private sector. All top civil servants became employed through five-year fixed-term contracts with the possibility of renewal, thus substantially diminishing their job security. 
Neither PSA1 nor PSA2 regulate and guarantee career advancement, and "automatic" promotion cannot be expected when entering the civil service. The Estonian civil service is very small, having actual career ladders with only $2-4$ levels. This often means that it is difficult to design smooth individual career paths, and there are limited opportunities for career progression and promotion. Accordingly, many people may reach the peak of their careers very quickly and then encounter a career plateau. Because the Estonian civil service is open and position-based on all hierarchical levels, inside and outside candidates have equal opportunities when vacancies are advertised. Mobility between the public and private sectors is encouraged.

Regarding the salary, before the reform, the civil service commanded relatively low prestige, and the level of remuneration of professionals was not competitive with salaries in the private sector (Järvalt and Randma-Liiv 2012). During reform, the main political agenda communicated to public and civil servants was to raise the basic salary of the civil servants in exchange for abolishing civil service pensions and seniority pay. However, although there was an increase in civil service salaries, the average salary in the labor market saw an even higher increase, and as a result, the competitiveness of the civil service as an employer did not increase remarkably, and the prestige of the civil service continues to be rather low after the reform. In addition, performance-based salary was introduced by PSA2. Even more importantly, civil service pensions and seniority pay were completely abolished so that civil servants have exactly the same retirement conditions as private sector employees.

There was yet another aspect of civil service reform, which can be described as a shift towards the "managerial" bargain. In PSA1, there were a central pay scale and centrally regulated job titles. Job titles were not specifically defined, but they were linked to pay grades. Every supervisor was able to decide which job titles to use, and there was no ex-post control over the use of job titles and pay grades. Therefore, despite the centrally regulated salary system, managerial discretion over the salary level was already rather high before the reform. By PSA2, managerial discretion over pay was increased even more, since central pay grades and job titles were abolished and each public-sector organization became responsible for its own salary system. To balance the increase in managerial discretion, it was decided to disclose the salary of all civil servants.

As for the outcomes of the reform, its general goal was to save costs by decreasing the number of civil servants and to increase the flexibility by abolishing the perceived "disparities" that there were between the civil service and private sector employment. According to the Civil Service Yearbook (Ministry of Finance 2016), the labor costs of central government have rather increased after the implementation of the civil service reform, and the general number of staff (including both civil servants and employees covered by the civil service) remained the same after the 
reform. Another goal was to improve the transparency of the salary system and to treat civil servants equally. Indeed, there are central guidelines for job evaluations, pay-grade design and the compensation system by the Ministry of Finance. However, individual organizations use them very seldom and lack the capacity to use them uniformly. As a result, compensation systems vary across central government organizations, and performance pay is rewarded based on different principles. In addition, because some institutions have better budgetary conditions, because salary policies of institutions are different, and because the level of human resource personnel varies, salaries for similar positions vary remarkably across institutions. According to the commitment survey commissioned by the Ministry of Finance (2015), main problems in the civil service are the opaqueness of the salary system and unequal treatment of civil servants.

\subsection{Competences}

Competences in public service bargain include requirements for civil servants as far as their formal education, knowledge, skills, experience and attitudes are concerned, which, in turn, is closely related to recruitment and selection processes, performance appraisal and in-service training.

In general, formal requirements for civil servants did not change much after the reform. The broad requirement both in PSA1 and in PSA2 is that the civil servant is an Estonian citizen who has at least a secondary education and is proficient in the Estonian language to the extent provided by law. In the international context, the requirement for secondary education is somewhat exceptional, as usually a university degree is expected from civil servants (especially in the higher ranks). Compared to PSA1, in PSA2 more specific requirements for foreign-language skills and job experience were put in place for top and mid-level managers at the ministries. More specific requirements for top civil servants were also under discussion during the preparation of the draft of PSA2, but after some discussions on the political level, it was decided that no specific educational requirements (e.g. a Master's degree) were needed, and "delivery" type competences were seen as sufficient to ensure professional public service. For top civil servants, experience from the private sector is highly valued. All in all, in both laws, formal requirements for education, knowledge and skills have been kept rather low in order to allow for a large variety of candidates with different sets of experience to enter the civil service. It must be noted, though, that while the law sets only minimum requirements, specific job descriptions and vacancy announcements usually provide for higher and more specific requirements (e.g. university degree and possession of specific knowledge and skills).

PSA1 left recruitment open for all posts in the civil service, the top civil service included. Open competitions for top positions were publicly announced. PSA2 made open competitions mandatory for all civil service positions. Recruitment and 
selection are organized independently by each public sector organization (with the exception of about 100 top civil servants). In addition, it became mandatory to publish all vacancies on a central web-page administered by the Ministry of Finance. Neither PSA1 nor PSA2 require candidates to pass written exams for entering the civil service. The most used selection method are a job interview and the assessment of the CV, thus emphasizing interview skills and previous experience rather than the evaluation of specific knowledge and skills. For top civil servants, a specific competency framework has been used since 2004 (Randma-Liiv et al. 2015). The final appointment decision is made by the appointing authority - Secretary Generals in ministries and Directors General in government agencies - a similar arrangement both by PSA1 and PSA2. Politicians are not involved in the appointment of new officials with the exception of Secretary Generals, who are appointed by the Cabinet of Ministers.

As for performance appraisal, PSA1 set down a regular mandatory appraisal by an assessment committee, PSA2 foresees a mandatory individual appraisal interview between a civil servant and his/her supervisor. In PSA1, the training budget was legally regulated and gave single public sector organizations security for the development of competences. With the reform, the previous legal framework of the training budget was abolished. The central training budget is remarkably dependent on the EU funds, and the importance of external support has been gradually increased. The content of training has changed as well - from a mix of generalist and specialist training towards pure specialist training arranged by individual organizations. Top civil servants have a generous development program with the main emphasis on managerial training (Randma-Liiv et al. 2015).

\subsection{Loyalty}

When it comes to loyalty and responsibility as components of the public service bargain, the question is to whom civil servants owe their loyalty and what the politico-administrative relations are. As top civil servants serve on the borderline of politics and administration, their loyalty issues deserve particular attention.

Loyalty-related issues in Estonia are closely linked to the broader understanding of roles that civil servants are expected to perform. There is no coherent understanding of politico-administrative roles in Estonian society (see also Tammekänd 2004). This can be explained by problems of a (still) newly democratic state where civil service development has been carried by legalistic-technocratic motives (see also Randma-Liiv et al. 2015), and a broader discourse on politico-administrative roles has been non-existent. Estonian civil servants are separately identifiable as individuals (vis-à-vis politicians) but are not free agents in any political sense - they pursue defined goals in a limited space of action. On the one hand, civil servants give oath of office by swearing that they will be loyal to the constitution of Estonia when entering the civil service. On the other hand, civil servants are expected to 
be loyal to political representatives in successive governments. Conflicts can easily arise if these role perceptions happen to differ from each other, or if different parties assign different weight to them. Consequently, the perceptions of roles of civil servants can vary considerably, and even ministers belonging to the same political party can have very different expectations from civil servants. This shows that in terms of role understanding and loyalty, the Estonian civil service system gives predominant importance to individual (unwritten) PSBs. Personal loyalty - including personal fit and trust among political leaders and civil servants - is as important as political loyalty. The politicization of the civil service is, however, one of the lowest in Central and Eastern Europe (Meyer-Sahling 2011).

PSA1 did not stipulate the top civil servants as a distinct category although the recruitment and selection processes of top executives differed from the rest of the civil service, and they have come to be treated as a special group for training and development purposes since 2004 (Randma-Liiv et al. 2015). PSA2 formalized the Top Civil Service. It distinguished it as a separate civil service category with special regulations for fixed-term service, recruitment, selection, assessment, and development. Both PSA1 and PSA2 state that Secretary Generals can be forced to leave in cases when the minister finds their collaboration difficult after one year of working together.

According to PSA2, the Government of the Republic formed a Council of Ethics to reinforce the core values and ethics of officials. Before the reform, the Code of Ethics was a part of PSA1, but after the reform, the Code was separated from PSA2, and now it is approved by the Council of Ethics. By that the Parliament distanced itself from the Code of Ethics and handed it over to the Council of Ethics.

Table 3 summarizes the main changes during the civil service reform in Estonia on the basis of the main components of PSB.

\section{Discussion and conclusions}

In general, the Estonian civil service represents an agency-type public service bargain with characteristics of pragmatic, hybrid-type PSB. After the civil service reform in 2012, the PSB moved towards the managerial PSB. The further shift towards the managerial PSB is evident in the greater emphasis on flexibility in employment relations, the use of fixed-term contracts, increased private-sector-style practices at all levels of the civil service, an emphasis on performance management, and the reduction of formal statutory employment protections (see also Bezes and Lodge 2015, 144). The managerial bargain implies more decision-making autonomy for top officials in exchange for increased responsibility. In the course of the reform, the already decentralized civil service system in Estonia added further managerial discretion by decentralizing the civil service salary system. The Estonian civil service reform was very much in line with the private sector practice, as several employ- 


\section{Table 3}

Main changes in the Estonian Public Service Act by the components of public service bargain

\begin{tabular}{|c|c|c|}
\hline & $\begin{array}{c}1995 \text { Public Service Act } \\
\text { (PSA1) }\end{array}$ & 2012 Public Service Act (PSA2) \\
\hline \multirow[t]{7}{*}{\begin{tabular}{|l|} 
Reward \\
component
\end{tabular}} & $\begin{array}{l}\text { Institutionally-based definition } \\
\text { of civil service }\end{array}$ & $\begin{array}{l}\text { Restriction of the definition of civil } \\
\text { service }\end{array}$ \\
\hline & $\begin{array}{l}\text { Limited number of fixed-term } \\
\text { appointments }\end{array}$ & $\begin{array}{l}\text { All top civil servants have fixed-term } \\
\text { contracts }\end{array}$ \\
\hline & Limited job security & $\begin{array}{l}\text { Further decrease in job security: } \\
\text { simplification of dismissals, same as in } \\
\text { private sector }\end{array}$ \\
\hline & $\begin{array}{l}\text { Central pay grades and pay } \\
\text { components }\end{array}$ & $\begin{array}{l}\text { Centrally defined pay components } \\
\text { (performance pay as a new component) } \\
\text { and limitations for bonuses with } \\
\text { mandatory disclosure of salaries }\end{array}$ \\
\hline & $\begin{array}{l}\text { Limited managerial discretion } \\
\text { over pay }\end{array}$ & Increased managerial discretion over pay \\
\hline & Civil service pensions & Abolishment of civil service pensions \\
\hline & Seniority pay & Abolishment of seniority pay \\
\hline \multirow[t]{3}{*}{$\begin{array}{l}\text { Competency } \\
\text { component }\end{array}$} & $\begin{array}{l}\text { Mandatory open competition for } \\
\text { senior civil servants }\end{array}$ & $\begin{array}{l}\text { Mandatory open competition for all civil } \\
\text { service positions }\end{array}$ \\
\hline & $\begin{array}{l}\text { Mandatory appraisal of civil } \\
\text { servants by the assessment } \\
\text { committee }\end{array}$ & $\begin{array}{l}\text { Mandatory individual appraisal interview } \\
\text { between civil servant and his/her } \\
\text { supervisor }\end{array}$ \\
\hline & $\begin{array}{l}\text { Trainings both for generalist and } \\
\text { specialist skills }\end{array}$ & $\begin{array}{l}\text { Trainings mainly focusing on specialist } \\
\text { skills, the increase of the importance of } \\
\text { managerial trainings }\end{array}$ \\
\hline \multirow[t]{2}{*}{$\begin{array}{l}\text { Loyalty } \\
\text { component }\end{array}$} & $\begin{array}{l}\text { Mostly permanent but some } \\
\text { fixed-term contracts for top civil } \\
\text { servants }\end{array}$ & $\begin{array}{l}\text { All top civil servants have fixed-term } \\
\text { contracts }\end{array}$ \\
\hline & Code of Ethics as part of PSA1 & $\begin{array}{l}\text { Code of Ethics separately from PSA2; } \\
\text { approved by the Council of Ethics }\end{array}$ \\
\hline
\end{tabular}

ment conditions of public and private sectors converged, and the service relationship for civil servants became more organization- and person-specific.

As for the reward component of PSB, the pre-reform arrangement resembled a mix of "pyramid"- and "turkey race"-type reward. As the reform decreased job security, increased the number of fixed-term contracts, increased managerial discretion over pay, abolished centrally regulated pay structure and increased the importance of performance pay, it reflects the most the "turkey race" type of reward. "Turkey race" is a typical example of the NPM-oriented competition- and individual-based type of reward. 
The civil service reform did not bring along major shifts in the competency component of the bargain. While the "delivery" type of the bargain was already prevalent in the pre-reform era, it got further strengthened in the course of reform. To some extent and in occasional cases, "wonk" and "go-between" bargains can also be identified in Estonia, but the "sage" type of bargain is completely missing in the civil service. The existing selection and appraisal instruments do not value technical skills as much as they could, thus the "wonk"-related characteristics can be found more in reform rhetoric than in the everyday functioning of the civil service. The Estonian competency bargain resembles a "deliverer" type of PSB because managerial skills are regarded as more important than technical skills, and in line with the managerial approach, result-orientedness is highly valued. Similarly to the reward component, the "delivery" type bargain is a typical feature of NPM.

The prevailing loyalty bargain in the Estonian pre-reform era used to be a "partnership"-type bargain according to which public servants work together with elected politicians but have no separate identity either in directing public organizations or in determining policy. This implies that the civil servants' loyalty to politicians tends to prevail over semi-autonomous performance based on the constitution and public interest (the latter being represented by "judge"-type bargain). Personal (rather than political) loyalty to supervisors dominates as typical of the hybrid-type bargain (Hood and Lodge 2006). The civil service reform did not have a major impact on politico-administrative relations and loyalty issues for the general civil service. There was, however, a change for top civil servants, shifting the loyalty component more towards "executive"-type bargain. With the introduction of fixedterm contracts for top executives, loyalty towards the (political) principal came to be of foremost importance, as renewal of these contracts depends on the satisfaction of a (political) superior, and in case of failure, blame would rest with the top executive. This is again an archetypal characteristic of the NPM model.

Table 4

Comparison of old and new public service bargains in the Estonian civil service

\begin{tabular}{|l|l|l|}
\hline & \multicolumn{1}{|c|}{$\begin{array}{c}\text { Old Public Service } \\
\text { Bargain } \\
\text { (PSA1: 1996-2012) }\end{array}$} & \multicolumn{1}{|c|}{$\begin{array}{c}\text { New Public Service } \\
\text { Bargain } \\
\text { (PSA2: since 2013) }\end{array}$} \\
\hline $\begin{array}{l}\text { Type of Public Service } \\
\text { Bargain }\end{array}$ & $\begin{array}{l}\text { Agency type (pragmatic) } \\
\text { PSB }\end{array}$ & $\begin{array}{l}\text { Agency type (pragmatic) } \\
\text { PSB }\end{array}$ \\
\hline Sub-type of PSB & Hybrid PSB & Moderate managerial PSB \\
\hline Reward component & $\begin{array}{l}\text { Mix of pyramid and turkey } \\
\text { race }\end{array}$ & Turkey race \\
\hline Competency component & Deliverers & Deliverers \\
\hline $\begin{array}{l}\text { Loyalty/responsibility } \\
\text { component }\end{array}$ & Partnership & $\begin{array}{l}\text { Mix of partnership and } \\
\text { executive type }\end{array}$ \\
\hline
\end{tabular}


Table 4 summarizes the shift from the old to the new PSB after the civil service reform in 2012.

It is interesting to observe that despite the widespread criticism of NPM (see, e.g., Nemec 2010; Randma-Liiv and Drechsler 2017 specifically for Central and Eastern Europe), the Estonian civil service reform presents a "textbook case" of managerial NPM-oriented reform. Typically of NPM-based PSB, result-orientedness and the importance of "delivery" within one organization are emphasized. Elements characteristic to post-NPM (e.g. boundary spanning and collaboration-oriented competences, team-based incentives, an outward-looking customer-focused approach) have been missing in the reform. Whereas the establishment of the Top Civil Service created the potential for addressing cross-boundary cooperation within the public service, this potential has not materialized in practice, since the development of top executives is limited to advancing individual managerial skills rather than developing them as a coherent group responsible for the whole-of-government approach (Randma-Liiv et al. 2015).

The longer-term consequences of such a pragmatic managerial-oriented civil service reform may affect all components of PSB. First of all, civil servants lost many of their distinct rewards through the reform. It is yet to be seen whether and how the reform abolishing civil service rewards may influence the attractiveness of civil service careers. The less job security there is, the more it should be compensated by other rewards (such as pay) in order to retain an optimal balance of PSB. Insufficient rewards may contribute to a vicious circle of temporary civil servants, including problems with recruiting new officials and a further increase in their turnover, ultimately leading to a "temporary state".

Second, limited qualification requirements provided by the law, the absence of written entrance exams and the opportunity for single organizations (and individual managers) to choose appropriate selection methods and make final personnel decisions indicate very high managerial discretion in the recruitment and selection process. This may not only lead to nepotism and even politicization, but the highly decentralized selection process facilitates the development of narrow "job-specific" competences rather than civil service generalists, thus further cementing the NPM approach rather than developing collaboration-oriented competences.

And third, the introduction of fixed-term contracts for all top civil servants is expected to change the loyalty relations, as the renewal of these contracts depends on the satisfaction of (political) superiors. Although fixed-term contracts are seen to encourage result-orientedness first of all, such arrangements can also be misused for political reasons (see, e.g., Althaus and Vakil 2013). Fixed-term contracts would create opportunities for not renewing contracts with politically unsuitable candidates and thus increase the importance of both political and personal loyalty in PSB. This, in turn, may lead to tendencies of politicization of top executives and consequently negatively influence the competence, independence and neutrality of 
civil service. The loyalty of civil servants may in turn shift towards instrumental, short-term and easily influenced or changing loyalty, thus challenging the fundamental values of democratic governance.

\section{Acknowledgement}

Research leading to this article was supported by the Horizon 2020 grant no. 726840 (TROPICO), the institutional research grant no. IUT19-13, and the project "Navigating the Storm: The Challenges of Small States in Europe", grant no. 587498-EPP1-2017-1-IS-EPPJMO-NETWOR

\section{References}

Althaus, Catherine and Thea Vakil. 2013. "Political Transitions: Opportunities to Renegotiate the Public Service Bargain." Canadian Public Administration/Administration Publique du Canada 56(3), 478-490.

Askim, Jostein and Tobias Bach. 2017. "Administrative Reforms, Politicization and the Selection of Heads of State Agencies in Norway." Paper presented at the ECPR conference, 6-9 September, in Oslo, Norway.

Bezes, Philippe and Martin Lodge. 2015. "Civil Service Reforms, Public Service Bargains and Dynamics of Institutional Change." In Frits Van der Meer, Jos C. N. Raadschelders, and Theo A. J. Toonen (eds). Comparative Civil Service Systems in the $21^{\text {st }}$ Century. $2^{\text {nd }}$ edn. London: Palgrave Macmillan, 136-161.

Burns, John P., Li Wei and B. Guy Peters. 2013. "Changing Governance Structures and the Evolution of Public Service Bargains in Hong Kong." International Review of Administrative Sciences 79(1), 131-148.

Dimitrova, Antoaneta. 2002. "Enlargement, Institution-Building, and the EU's Administrative Capacity Requirement." West European Politics 25(4), 171-190.

Hondeghem, Annie and Karolien Van Dorpe. 2012. "Performance Management Systems for Senior Civil Servants: How Strong is the Managerial Public Service Bargain?" International Review of Administrative Sciences 79(1), 9-27.

Hood, Christopher. 2000. "Paradoxes of Public-Sector Managerialism, Old Public Management and Public Service Bargains." International Public Management Journal 3, 1-22.

Hood, Christopher. 2001. "Public Service Bargains and Public Service Reform." In B. Guy Peters and Jon Pierre (eds). Politicians, Bureaucrats and Administrative Reform. London and New York: Routledge, 13-23. 
Hood, Christopher. 2002. "Control, Bargains, and Cheating: The Politics of Public Service Reform." Journal of Public Administration Research and Theory 12(3), 309-332.

Hood, Christopher and Martin Lodge. 2006. The Politics of Public Service Bargains: Reward, Competency, Loyalty - and Blame. Oxford: Oxford University Press.

Järvalt, Jane and Tiina Randma-Liiv. 2010. "Public Sector HRM: The Case of no Central Human Resource Strategy." Baltic Journal of Management 5(2), 242-256.

Järvalt, Jane and Tiina Randma-Liiv. 2012. "Starting from Scratch: Rewards of High Public Office in Estonia." In Marleen Brans, and B. Guy Peters. Rewards for High Public Office in Europe and North America. London: Routledge, 190-208.

Lægreid, Per and Lois Recascino Wise. 2015. "Transitions in Civil Service Systems: Robustness and Flexibility in Human Resource Management." In Frits Van der Meer, Jos C. N. Raadschelders and Theo A. J. Toonen (eds). Comparative Civil Service Systems in the $21^{\text {st }}$ Century. $2^{\text {nd }}$ edn. London: Palgrave Macmillan, 203-222.

Lodge, Martin and Derek Gill. 2011. "Toward a New Era of Administrative Reform? The Myth of Post-NPM in New Zealand." Governance: An International Journal of Policy, Administration, and Institutions 24(1), 141-166.

Lodge, Martin and Christopher Hood. 2012. "Into an Age of Multiple Austerities? Public Management and Public Service Bargains across OECD Countries." Governance: An International Journal of Policy, Administration, and Institutions 25(1), 79-101.

Meyer, Renate E. and Gerhard Hammerschmid. 2010. "The Degree of Decentralization and Individual Decision Making in Central Government Human Resource Management: A European Comparative Perspective." Public Administration 88(2), 455-478.

Meyer-Sahling, Jan-Hinrik. 2011. "The Durability of EU Civil Service Policy in Central and Eastern Europe after Accession." Governance 24(2), 231-260.

Ministry of Finance. 2015. Civil Service Yearbook 2014. Tallinn: Ministry of Finance. Ministry of Finance. 2016. Civil Service Yearbook 2015. Tallinn: Ministry of Finance.

Nemec, Juraj. 2010. "New Public Management and its Implementation in CEE: What Do we Know and where Do we Go?" The NISPAcee Journal of Public Administration and Policy 3(1), 31-52.

Pesti, Cerlin and Tiina Randma-Liiv. 2017. Report on Public Administration Reform Trends and Reform Dynamics in Estonia. A report prepared within the EC's EUPACK project. 
Peters, B. Guy. 2010. The Politics of Bureaucracy: An Introduction to Comparative Public Administration. $6^{\text {th }}$ edn. London: Routledge.

Randma-Liiv, Tiina and Wolfgang Drechsler. 2017. "Three Decades, Four Phases: Public Administration Development in Central and Eastern Europe, 1989-2017." International Journal of Public Sector Management 30(6-7), 595-605.

Randma-Liiv, Tiina, Annika Uudelepp and Külli Sarapuu. 2015. "From Network to Hierarchy: the Evolution of the Estonian Senior Civil Service Development System." International Review of Administrative Sciences 81(2), 373-391.

Rouban, Luc. 2012. "Politicization of the Civil Service." In B. Guy Peters and Jon Pierre (eds). Handbook of Public Administration. $2^{\text {nd }}$ edn. London: Sage Publications, 380-391.

Salomonsen, Heidi Houlberg and Tim Knudsen. 2011. "Changes in Public Service Bargains: Ministers and Civil Servants in Denmark." Public Administration 89(3), 1015-1035.

Savi, Riin and Tiina Randma-Liiv. 2016. "Public Sector Reform in Estonia: The Abundance of Piecemeal Initiatives." In Gerhard Hammerschmid, Steven Van de Walle, Rhys Andrews and Philippe Bezes (eds). Public Administration Reforms in Europe: The View from the Top. Cheltenham, UK, and Northampton, MA, USA: Edward Elgar Publishing, 85-95.

Steen, Trui and Frits van der Meer. 2011. "Public Service Bargains in Dutch Top Civil Service." Public Policy and Administration 26(2), 209-232.

Tammekänd, Katri. 2004. “Tippametnike politiseerumine: kas ohu märk või loomulik areng?" [Politicization of Senior Civil Servants: A Sign of Danger or Natural Development?]. Riigikogu Toimetised 9, 117-122. 